NEBRASKA: Laws 1933, c. 65 . Authorizes courts to stay proceedings upon application and cause shown, and to fix terms as to possession, crops, care of property, taxes, etc.

See c. 4I for a provision depriving the courts of power to enter a deficiency judgment, without recital of the emergency as its justification and no limitation as to duration of the provision.

North Carounna: Laws of 1933 , c. 275. Fair value of the land (not sale price) to determine deficiency judgment.

NoRTh Dakota: Laws of 1933 , c. 157 . Extends all periods of redemption for an additional year. No compensation provided. This act held invalid in State v. Klein, 249 N.W. II8 (N.D. 1933) except as to mortgages subsequent to act.

C. 158 . Foreclosure by advertisement abolished except on mortgages held by the State or by the University.

Oregon: (r933) H. J. R. 2. Appoints a joint committee to consider the subject and introduce a bill, but apparently no legislation passed.

SouTH DAkota: Laws of I933, c. I35. Foreclosures by advertisement suspended when requested by mortgagor.

C. I37. Redemption period extended additional year on condition that the mortgagor pay taxes, back interest, interest since the sale, interest one year in advance, and the costs of the foreclosure.

C. 138 . Prohibits deficiency judgments.

Wisconsin: Laws of I93x (Special Session), c. 29, § 7. Extends period of redemption additional year, mortgagor to pay taxes and interest.

Laws of 1933 , c. II, I25.

\title{
BRITISH AND AMERICAN UTILITIES: A COMPARISON
}

\section{Marshali E. Dimock*}

W

HUE Great Britain (and most European countries for that matter) has been experimenting with mixed undertakings and public utility trusts, our American states have been content to muddle along with the railroad and public utility commissions in forty-seven states. ${ }^{x}$ Public utility regulation is preeminently American, although the public utility concept was derived from English rather than from American sources. ${ }^{2}$ In contrast with the maze of learned articles on public utilities which have been produced by American writers, information on British public utilities is

* Associate Professor of Public Administration, University of Chicago.

× Mosher and Crawford, Public Utility Regulation, New York, I933. Delaware is the only state that has not created a public utility commission.

2 B. P. McAllister, Lord Hale and Business Affected with a Public Interest, 43 Harv. L. Rev. 759 (1930); Walton Hamilton, Affectation with a Public Interest, 39 Yale L. Jour. Io99 (1930). 
"fragmentary."3 Almost anomalously, however, the British have evidenced more inventiveness in dealing with public service enterprises than have we who lay so much emphasis on public utilities. Because of parliamentary supremacy in Great Britain, British courts are not drawn into "the conflict over the most controversial social and economic issues of the day" as are American courts because of questions involving due process of law. The law relative to valuation and expropriation is more definite in Great Britain than it is in the United States. The British rule may be compared with Mr. Justice Brandeis' "prudent investment theory," 4 and hence, theoretically at least, it avoids the horns of the original "cost versus the reproduction cost" dilemma. The courts will not set aside rates established by Parliament when the owners contend that such schedules are confiscatory. The upshot of all this is legislative and administrative control, and the avoidance of expensive and almost continuous litigation. A comparison of British methods of public utility organization, control, and management possibly may suggest some modifications and new departures for the United States whereby the widespread criticism of commission regulation and the new problems arising out of the federal reconstruction program may be met. ${ }^{5}$

\section{THE TRADITIONAI METHODS OF REGULATION}

The legislative and administrative techniques of regulation in the United States were patterned closely on those which had evolved in Great Britain in the third quarter of the nineteenth century. Although Parliament had imposed restrictions on inns, roads, canals, water, gas, and other essential services at an earlier period, ${ }^{6}$ the regulation of railways between I854 and $\mathrm{x} 873$ furnished the real institutional foundation for both British and American public utility regulation. The railway commission which was established by Parliament in 1873 , and which was superseded by the Railway and Canal Commission in $\mathrm{x} 888$, laid the foundation for the In-

3 The writer's book, British Public Utilities, is in press. It represents a year's research as a Social Science Research fellow.

4 State of Missouri ex rel. Southwestern Bell Telephone Co. v. Public Service Commission of Missouri, et al, 262 U.S. 276, 308, 43 Sup. Ct. 544, 553, 67 L. Ed. 98r, 994, 3I A. L. R. 807 (r922).

5 The Federal Trade Commission investigations of electrical utilities; The Knight Commission Report in New York, I930; the Pennsylvania investigation of I93I, the Massachusetts inquiry, 1930, and the sweeping changes in the Oregon law, 1930, are symptomatic. See William E. Mosher, Electrical Utilities: The Crisis in Public Control (New York, I929); Mosher and Crawford, Public Utility Regulation (New York, I933); and Keezer and May, The Public Control of Business (New York, I930).

${ }^{6}$ F. N. Keen, The Law Relating to Public Service Undertakings (London, I925), c. I. 
terstate Commerce Commission in I887.7. Although laissez faire was "a local and temporary expedient," and a marked exception to the long and continuous history of state control, ${ }^{8}$ the so-called intervention of the state in the progress of railway development after 1873 marked the end of the period of uncontrolled business expansion and signalized the beginning of the modern period of public utility regulation. For the first time permanent administrative machinery was created for the supervision of undertakings which had been given rights of eminent domain and monopoly privileges. These bodies were charged with the duty of enforcing compliance with legislation relative to the service, practices, and rates of public utility companies. This was the theory of Victorian regulation, a system of public control which was not destined to take a foothold in Europe, and which has lost most of its popularity in Great Britain, but which is still the standard form of public utility regulation in the United States.

The administrative tribunal is the symbol of Victorian regulation. An agent of the legislature, identified in composition and functioning with the administration, performing acts which are distinctly judicial, the regulatory commission has been one of the principal agencies of constitutional and economic growth. The public utility commission is unknown in Europe, where heads of departments, assisted by advisory committees, regulate the undertakings of private companies. In most countries outside of the United States regulation is unimportant because the great majority of public service undertakings are owned in whole or in part by governmental subdivisions. Public ownership is also extensive in Great Britain, where roughly two-thirds of the electrical distribution, forty per cent of the gas supply, four-fifths of the local transport services, and ninety per cent of the water undertakings are publicly owned and operated. ${ }^{9}$ Dissatisfaction with regulation has been an important factor in the expropriation of private companies and the establishment of municipallyowned services.

In Great Britain there are public utility commissions for railways, ${ }^{10}$ road transport, ${ }^{\mathrm{Ix}}$ and electricity. ${ }^{\mathrm{Xz}}$ The greater importance attached to regulation in the United States is suggested in part by the much greater number of regulatory commissions, there being forty-seven state tribunals in addi-

7I. L. Sharfman, I The Interstate Commerce Commission (Ist ed. x93I), c. x.

${ }^{8}$ Herman Finer, State Activity before Adam Smith, ro Public Administration, 157 (1932).

9 Liberal party, Britain's Industrial Future (1928), 68-74.

ro The Railway and Canal Commission (I888) and the Railway Rates Tribunal (I92I).

Ir A metropolitan commission in London and one in each of twelve provincial districts.

22 The Central Electricity Board (1919). 
tion to the Interstate Commerce Commission, the Federal Radio Commission, and the Federal Power Commission. What do the coming years hold in store for the British and the American public utility commissions? Can regulation succeed, or has it failed? Is the idea of setting up one organization to watch and control another organization fundamentally sound, or must success be expected from an unregulated operating concern, either wholly or partly public in ownership and management?

The view is now widely held in Great Britain that Victorian regulation, involving as it does the creation of one set of officials to scrutinize and to control the actions of other officials, is definitely antiquated. Regulation has not been a success. Generally speaking, the older method of regulation has proved timid, inelastic, and ineffective. Dissatisfaction with Victorian regulation does not come from the Liberals and the Socialists alone; the Conservative party has been responsible for the creation of all except one of the.public utility trusts. These new quasi-governmental undertakings are regarded as an alternative to regulation. As a matter of fact, Conservative members of Parliament are generally more outspoken in their criticism of administrative regulation than the Liberals. There is a widely held view among British business men that "A regulated business is worse than no business at all." In some cases, this sweeping condemnation merely represents the vehemence of a reactionary, but in the majority of cases convincing reasons are given for discontent with continuous regulation by administrative tribunals and government departments.

The traditional method of regulation is not designed to produce a public service philosophy on the part of those who operate the undertakings. Experience has demonstrated that this is one of the most insuperable faults of regulation. Regulation begins with the wrong assumptions. Public control is regarded as "intervention." Profit-making for the investors remains the primary consideration. Hence the relations between the utility and the government become a game. Under the rules of the game, the public utility officials match their wits with the regulatory officials. Service to the public is desirable insofar as it increases business and dividends. In other words, beginning with the assumption that all business is private and that regulation represents onerous burdens which have been imposed by politicians, the public utility officials are constantly on the defensive. The stockholders judge the management's success by dividends; this usually means that public utility officials "must get away with" as much as possible. Watered stock, holding company juggling, lowering of quality when possible, unequal treatment of congested and undeveloped areas, high-powered propaganda, pressure to appoint regulatory officials who 
will be "safe"-these results of regulation have flowed as naturally from British regulation as they have from American.

It is possible to create public utilities in which voting stockholders and elastic dividends are eliminated. This is one of the objectives underlying the public utility trust, which begins with the assumption that the business is public. Public service is the controlling consideration. The profit motive and public utility service are incompatible..$^{13}$ This elementary truth seems to be more generally appreciated in Great Britain than in the United States.

Regulation creates the wrong atmosphere. Interference is universally resented by men in every kind of pursuit. So-called "effective" regulation invariably involves a division of responsibility for management between the operating officials and the regulators. The results of this system impair the efficiency of the service. Responsibility cannot be definitely fixed in every case; the quantity of restrictions is frequently considered the measure of results; rules and regulations laid down by the legislature usually outlive their usefulness. The regulated undertaking does not have that elasticity and freedom of management which are necessary foundations of progressive management. Experimentation is virtually impossible. The status quo tends to become the equivalent of effective regulation.

The personnel problem of British and American public utility commissions has received very little attention and yet this is undoubtedly one of the most vulnerable points of the regulatory process. The administrative tribunal is usually commended for its "expertness," but in most cases a candid examination reveals that this reputation is undeserved. To be sure, men like Milo R. Maltbie, Clyde L. King, and David E. Lilienthal, who are really technically trained commissioners, have in some cases been appointed to American tribunals. Most of the state commissions are anything but expert, however. A study of the previous callings of the members of state public utility commissions in I929 revealed that there were seventy-nine lawyers, thirteen engineers, five journalists, twenty-nine business men and bankers, seventeen farmers, twelve industrial workmen, and nine government employees, giving a total of $164 .{ }^{x 4}$ Most of the appointments to American public service commissions are patently "political." Only five American states have incorporated requirements concern-

13 "This policy" (the coordination of national transport facilities), stated members of the Royal Commission on Transport, "can only be attained through an organization which works for service rather than profit." Final Report, Royal Commission on Transport, Cmd. 375I (r931).

${ }^{14}$ Francis X. Welch, The Trend from Lawyers to Laymen as Commissioners, 4 Pub. Util. Fort. 8or (rg29). 
ing training and experience into their public utility statutes..$^{x 5}$ Under the present laws, it would be very surprising if, at one time or another, most American commissions were not considered to be "utility-controlled."

One of the foundation stones of public utility regulation in Great Britain has been the recruitment of commissioners from interest groups. Convincing reasons have appeared for believing that interest representation is usually an unsound element in public utility control. ${ }^{16}$ The Railway Rates Tribunal is the best example of a system of interest representation which, until recent years, was considered an indispensable feature of public utility control. The Rates Tribunal has three members, one of whom must be a lawyer, another a trader, and the third a person who has had practical experience in railway management. Of the present members, the lawyer was a former railway counsel; the railway man was Vice-President of the L.M.S. Railway; and the third member was an official of the Iron and Steel Manufacturers' Association-a trade association which is more dependent upon rail transport than is any other industrial group.

This is one form of "expertness," but not the one that seems to be most desirable in the public interest. As hard as they may try, members of a regulatory tribunal who have been associated with competitive interests for most of their lives are never quite able to detach themselves from their natural predilections and their former attachments. Nor are they trained for the comprehensive, objective approach which persons like Maltbie, King, and Lilienthal obtain from their academic training. Most persons who have closely observed the results of interest representation in British public utility regulation find themselves in agreement with the Liberal Industrial Inquiry, which concluded that the representation of "interests," consumers' or other, should be discontinued.77

Public utility regulation becomes less effective when the personnel, the procedure, and the findings of the administrative tribunal become too "judicial." This rather dogmatic statement is strongly supported by British regulatory experience, and also by the records of American tribunals which have become too "judicially-minded." The "administrative" tribunal, composed of technicians, and which has created rules and standards out of its own experience, has contributed most to the improvement of public utility regulation. ${ }^{18}$

15 These are Nevada, Michigan, Virginia, West Virginia, and Wisconsin. The best consideration of personnel is found in Mosher and Crawford, Public Utility Regulation, c. 5 .

${ }^{16}$ With wider experience the writer has had to revise his views since writing, Special Courts for Public Utility Cases, 20 Natl. Muni. Rev. 69r (r93r).

${ }_{77}$ Britain's Industrial Future, 80.

${ }^{18}$ Wisconsin, California, and Massachusetts probably lead in this respect. For a good discussion of the differences between "administrative" and "judicial" tribunals see William A. 
The Railway and Canal Commission, which Parliament created in I888 and whose railway jurisdiction has now almost completely disappeared, is the most outstanding example of "judicial" public utility regulation. The chairman of the railway court, a judge of the High Court, dominates the two lay members. The proceedings of the Commission are almost identical to a court of law. From almost the very beginning the business community and the railways objected to the judicial character of the tribunal; they sought informality and the elevation of the technician. The creation of the Railway Rates Tribunal in $\mathrm{x} 92 \mathrm{I}$ was largely at revolt against judicial regulation. The new tribunal took over most of the jurisdiction of the Railway and Canal Commission, and in 1932 an important House of Commons committee recommended the latter's abolition.

A field survey conducted by Professors Mosher and Crawford in I930 revealed that the public utility commissions in only two out of twentyeight states studied, were considered "judicially-minded." I9 This is an interesting - and in the writer's view an encouraging-sidelight on American public service commissions. The comment on the Maine commission, as made by the investigator, is of particular interest in view of the adoption of a judicial rôle by certain commissioners. It read as follows: "During the major portion of its history the commission has attempted to be 'judicially' minded, which in effect in many instances meant that the advantage was with the utility since the public was poorly represented in comparison with the expert representatives of the utilities. There is more evidence now of a 'public-minded' attitude on the part of the commission." 20

In the past three or four years, the trend toward "public-minded" commissions, as illustrated by New York, Pennsylvania, Wisconsin, and Oregon, seems to be due in part at least to dissatisfaction with the former tendency to "judicialize" public utility commissions. Oregon's shift to a one-man commission in r930 is a striking example of the overthrow of a commission of three members, which functioned very much like a court,

Robson, Justice and Administrative Law (London, $x 928$ ), c. 3, 6; the reader is also referred to Dean Roscoe Pound, Administrative Application of Legal Standards, American Bar Association Reports, 445 (Igrg).

${ }^{39}$ Seventeen commissions were adjudged "utility-minded," six (Massachusetts, Michigan, Nevada, New Hampshire, Vermont, and California) were considered "public-minded," and no opinion was hazarded in the case of two states. Public Utility Regulation, op.cit., supra, note I, $57 \mathrm{n}$.

${ }^{20}$ Ibid. 
and the substitution of a commissioner who is responsible to the Governor, and who acts as the consumers' champion. ${ }^{2 x}$

There are two defects from which American public utility regulation suffers, namely frequent appeals and great expense, which are not found in British regulation. The principal reason for the difference-judicial review of legislation and due process of law-have already been mentioned. Then too, Parliament has made it clearer than has Congress or the state legislatures that administrative finality is really demanded. Although the customary statutory distinction is drawn between "fact" and "law," the British courts have not shown a tendency to develop absorptive theories, as have American courts, regarding "jurisdictional facts" and "mixed questions of law and fact." ${ }_{22}$ As a matter of fact, only six decisions of the Railway Rates Tribunal have been appealed in ten years, and the Commission was sustained in all except two of them.

The comparative cost of public utility regulation in Great Britain is no where near so great as in the United States. The avoidance of protracted and expensive litigation is the principal reason for this. The fixed expenses of American public service commissions are nominal, amount: ing to only $\$ 7,100,000$ for state regulation in I929-I930. ${ }^{23}$ Regulation is seriously impaired because of inadequate appropriations. New York, which has a comparatively large budget, has attempted to regulate utilities with an investment of upwards of $\$ 3,000,000,000$, on appropriations approximating $\$ 1,000,000 .^{24}$ The heavy financial load which is passed on to the consumers is primarily the result of appeals to state and federal courts. "The present enfeeblement of utility administration by the states," Felix Frankfurter has stated, "is in no small measure due to interference in administration by the lower federal courts." ${ }^{26}$ The New York Telephone case alone cost the company, in the period between IgIg and r929, about $\$ 5,000,000.27$ This figure did not include the commission's or the courts' expenses, all of which must ultimately be borne by the consumer. As Mr. Justice Brandeis once observed, "The public relations of

${ }_{2 x}$ Marshall E. Dimock, The Prospect for Administrative Tribunals, 20 Cal. L. Rev. I62. (1932); Guy S. Claire, Recent Utility Regulation in Oregon, Ir Ore. L. Rev. 338 (I932).

22 John Dickinson, Administrative Justice and the Supremacy of Law (Cambridge, I927), c. 6, Ir; Kenneth F. Burgess, Recent Attempts to Immunize Commission Orders Against Judicial Review, r6 Iowa L. Rev. 53 (1930).

${ }_{23}$ Mosher and Crawford, op. cit., supra, note I, 7o.

24 Ibid., 69.

${ }^{25}$ C. B. Cooke, Jr., Why Rate Cases Cost Too Much, I2 Pub. Util. Fort. I6 (I933).

${ }^{26}$ The Public and its Government (New Haven, r930), I2r.

27 Ibid., Ioo. 
the utility to the community are apt to become more and more strained. And a victory for the utility, may in the end, prove more disastrous than defeat would have been."

The conflict and chaos arising from disputes over valuation theories, and the ineffectuality of attempts to control holding companies are clearly the most serious defects of present-day utility regulation in the United States. ${ }^{28}$ Neither of these problems has become acute in Great Britain. The development of electrical holding companies in Scotland, the Midlands, the Home Counties, and Wales-Western England, however, has begun to cause concern to the Electricity Commission and the Ministry of Transport. American interests and a Scotch public utility official have set the pace. Although the holding company device has created some unsolved problems in the electricity field, holding companies generally would not seem to be a source of serious concern to British regulation.

Unlike the United States, British regulation is not complicated by state lines. Territorial restrictions on the jurisdiction of the regulatory tribunal are therefore not found. Moreover, holding companies are placed in an unfavorable position because they cannot become "statutory" companies; they may be formed only under the Companies Acts. This means that they cannot obtain rate-fixing powers and other privileges appertaining to statutory public utilities. Holding companies are not subject to regulation, but if the regulatory commission finds in the accounts of an operating undertaking any charge which has been imposed by a holding company, and if said charge is considered unreasonable, the permissible earnings of the operating company may be reduced by the amount of the disallowed charge. From this decision there is no legal recourse. Nevertheless, the rates of electrical utilities controlled by holding companies are generally higher than those of other companies, and in several cases they are twice as high as those of municipally-owned services. In all probability, the holding company development will create problems of more serious import, particularly in the administration of the law, than most British officials realize at the present time.

Commission regulation results in the distribution of responsibility among three or more members; the result is that real responsibility is very difficult, if not impossible, to obtain. A single official can be criticized, but it is almost impossible for the public to find the source of the difficulty when from three to seven members hand down an unpopular decision.

${ }^{28}$ Keezer and May, The Public Control of Business, c. 7, 9; H. W. Laidler, Concentration in American Industry (New York, I93r), Part III; W. E. Mosher, Electrical Utilities, c. 3, 4; Mosher and Crawford, Public Utility Regulation, c. 23-28; Lilienthal and Handler, Recent developments in the law of public utility holding companies, 3I Col. L. Rev. I89 (I93I). 
Where governmental administration has been improved, the independent commission has usually been abolished or else has been attached in an advisory capacity to a single-headed department. This is the system which is found universally throughout Europe and the Scandinavian countries. ${ }^{29}$

The movement for administrative integration, and the demand for "public-minded" utility regulation, may lead to important modifications or changes in the status of detached public utility commissions in the United States. The change in Oregon may be a significant omen. In the federal government, it would be surprising if, during the course of the next few years, the Interstate Commerce Commission, the Federal Trade Commission, the Federal Radio Commission, and the Federal Power Commission were not drawn into organic connection with major administrative departments of the government. The Federal Trade Commission and the Federal Radio Commission are under the wing of the Department of Commerce, for many practical intents and purposes, already. A Department of Communications having general coordinating control over the Post Offce, telegraphs, telephones, radio, and perhaps electrical power, would be able to absorb the Federal Radio Commission and the Federal Power Commission. This sort of functional organization has been adopted in several of the leading European countries. Coordination of policy and public control are obtained thereby, while at the same time the services within the constellation are given a high degree of operating freedom. The same solution might be applied to national transport. A Department of Transportation might be responsible for railway, bus, river, and air facilities. The Interstate Commerce Commission would naturally occupy a central position in such an organization. The creation of the office of Federal Coordinator of the railways already points in the direction of a more comprehensive coordination and greater administrative integration.

The leaven which has been rapidly changing the character of British public utility control in recent years is still at work. Each week the demand for a coordinated scheme of national transport gains adherents and seems nearer fulfillment. The ruinous competition between road and rail, which has reached an acute stage since the ${ }_{92} 6$ strike, appears to be insoluble except by national coordination. Newspaper correspondents report that a National Transport Board, an operating rather than a regulatory body, appears imminent. If so, the two railway tribunals and the thirteen traffic commissions would probably be discontinued or else transformed into advisory bodies connected with the Ministry of Transport. Moreover, when the national electricity scheme has been entirely com-

${ }^{29}$ Orren C. Hormell, Public Utilities Abroad (Syracuse, 1930). 
pleted (in from three to five years), the Electricity Commission will probably be considered an extra spoke in the wheel. Its raison d'être is open to question now. What regulatory functions it possesses are duplicated in the Ministry of Transport.

Although prophecy is dangerous, it would appear that Victorian regulation has almost reached the end of the trail in Great Britain. Regulation has proved timid, and on the whole not as effective as in the United States. Profits of from ten to fifteen per cent are still commonly earned by electricity companies. The quality of service varies widely in different parts of the country. The administrative tribunals are handicapped by the absence of technical staffs of their own. They must call upon the Ministry of Transport or private consultants. Failure to effect sufficient coordination between the regulatory tribunals and the Ministry of Transport has led to the loss of initiative and responsibility. ${ }^{30}$ Independent regulatory tribunals are out of place in a responsible form of government. National planning of basic industries and public services, and the maintenance of uniform policies relative to all of them, seem to demand a central administrative authority. The present maze of regulatory bodies can never provide this element; instead it militates against coordination and growth. What is needed is effective, centralized control over public utilities, along with the highest degree of operating freedom which is compatible with the public's interest. These objectives are much more likely to be obtained by the new public utility trusts and the mixed undertakings than by the chess game of regulation.

THE PUBLIC UTILITEES TRUST AND THE MUXED UNDERTAKING

A great deal of public utility history has been made in Great Britain during the past six or seven years. A national plan for the generation and transmission of electricity has been worked out and put into operation. All of London's transport facilities, steam railways, subways, tramways, and buses have been formed into an integrated monopoly. A single national authority has been entrusted with the preparation and broadcasting of all radio programs. These are far-reaching developments, but they are probably only the first of several others. As an American journalist, William Hard, has said, "the whole intellectually dominant element in Britain's Conservative party are headed straight toward a national governmental planning of Britain's entire basic economic life."

All of the ventures in national planning mentioned above have taken

${ }^{30}$ On the central position occupied by the Ministry of Transport in British public utility control see Herbert Morrison, Socialization and Transport (London, I933), 17 I ff. 
place since r926. One of the most significant features of the whole development is that a form of organization known as the "public utility trust" or the "public corporation" has been selected in each case..$^{3 x}$

The British have turned their backs on regulation. Experience has taught them that the best results are obtained through responsible administration rather than by cumbersome regulation; that voting stockholders and speculative profits should be eliminated from public utilities; and that public service officials are trustees for the government and for the consumers.

The principles underlying the public utility trust are these:

I. Services which are indispensable to the consumer and which are vital to national economic development should be brought into a monopoly. The elimination of the detrimental results of competition, and dissatisfaction with prices and practices which are permitted under regulation are the principal inducements.

2. The profit motive must be eliminated, and the public service principle must be put in its place.

3. There are no voting stockholders in the newer public utility trusts. So long as the management is controlled by the stockholders, the profit incentive cannot be eliminated. Directors are replaced by governmentappointed Trustees.

4. Fixed interest payments are established by the statutory provisions creating the quasi-governmental monopoly. Stock in expropriated undertakings is converted into stock in the public utility trust. Interest payments in different undertakings vary between three and five per cent. Stock takes on the characteristics of bonds. The stock is not tax-exempt. Sinking fund provisions are established according to which the stock is retired at definite periods ranging from twenty to sixty years.

5. Surplus earnings are either used to reduce charges to the consumer or are turned into the general coffers of the government. ${ }^{32}$

6. Definite statutory limitations and business principles are established, eliminating the necessity of constant and meticulous supervision by government departments. The removal of the profit incentive is the most important of these.

7. Trustees, usually five or seven in number, are appointed by the government on the basis of their public spirit and their general ability. Inter-

${ }^{3}$ The Port of London Authority ( 1908 ) is a forerunner of the modem public utility trust. The Metropolitan Water Board is another good example of earlier experience with the public corporation.

${ }^{32}$ The former alternative is usually the case, the only notable exception being broadcasting which derives its revenue from a licensing system administered by the Post Office. 
est representation and party selection are expressly eliminated. Both Labor and Conservative Governments have appointed more trustees from other parties than from their own. This has become a tradition, and it is one of the most necessary features of the trustee principle.

8. The business management of the public service undertaking is entrusted to a general manager, who is appointed by the trustees. The salaries of the trustees and of the general manager are fixed by law. The general manager is given a wide discretion in appointments, organization, contracts and management. The selection of a manager of great ability and initiative is one of the most essential requirements of the public corporation. Fortunately the British have produced administrators of high calibre in men like Sir John Reith and Lord Ashfield. The employees of the public utility trust are not subject to civil service requirements. It has been customary, however, to adopt some of the best features of the Civil Service system.

9. The Minister in charge of the department of government most closely related to the work of the public utility trust has, as representative of the legislature, an ex officio responsibility in relation to the public corporation. Thus the Postmaster-General has statutory duties in relation to the British Broadcasting Corporation, as has the Minister of Transport in connection with the Central Electricity Board. The Minister, however, does not interfere in policy or in management. In Parliament he answers only such questions pertaining to the public corporation as he chooses; in practice these are very few and relate only to fundamental issues. The ministerial link is established as a reserved power which can be used if necessity requires it.

Io. Treasury approval is required before additional securities can be floated, and a governmental audit may be demanded if the Government is not satisfied with the regular audit of a firm of certified public accountants. In addition, periodic financial reports are required which must be sold to the public at a small cost.

The above generalizations are subject to modification in some cases. Transport, electricity planning, and broadcasting present problems which cannot be solved by the application of stereotyped formulae. In the case of the London Transport Board, for example, appointments are made by socalled "Appointing Trustees" who are selected from various professional, economic, and governmental groups. ${ }^{33}$ This appears to be a thoroughly bad principle, because it complicates the administrative machinery and completely destroys responsibility for appointments. There is a wide-

${ }^{33}$ Herbert Morrison, Socialization and Transport, I6I ff. 
spread belief in Great Britain that this particular feature will be removed within the near future. The general ideas underlying the public utility trust, however, are substantially as stated above.

The results so far obtained from the operation of the newer public utility trusts are, on the whole, encouraging. Most men in British public life, including a section of the Labor party ${ }^{34}$ under the leadership of Herbert Morrison, a former Minister of Transport, subscribe to the view expressed in these words: "the public utility authority (trust) is the modern conception of dealing with monopoly services. .... The public utility authority is the organ to which men both of socialistic and individualistic predispositions are turning to conduct such services as are agreed to be best conducted as monopolies." 35

The eventual success of the public utility trust would appear to depend upon several important factors, the principal ones being whether adequate incentives have been provided, whether the plan can be kept free from business and political favoritism, whether first-rate leadership can be secured, and whether employees will be guaranteed a fair deal. Only the first two of these points will be discussed at this time.

The elimination of the profit motive should improve the quality of service, rather than act as a damper on the spirits of the officials..$^{36}$ This observation seems to be particularly applicable to Great Britain, where men of the greatest abilities have for generations been trained for public service instead of for profit-making. The fact that the most able young men in Great Britain enter the Civil Service is the best proof of this. The public service ethic has not captured American leaders so extensively as it has in Great Britain, but rapid changes in this direction have set in since I929. It does not seem too sanguine to expect that Americans will develop a new standard of values during the next few years, as a result of which public service will dominate the country's government and business leaders, replacing the cynical philosophy of selfishness which brought the country to collapse in I929.

In order to be run on "business-like" lines a commercial service does not need to make profits. On the other hand, all public utility trusts in Great Britain are required to be self-supporting. The consumer must pay for what he gets, and there is no question of any subsidy or guarantee from

34 Within the past two years the majority of the Labor party have grown unfriendly toward the public utility trust, because they do not find in existing examples of the public corporation adequate provision for labor representation in policy-formulation and management.

35 Lord Wolmer, Post Office Reform (London, I932), 201.

${ }^{36}$ On this subject see my recent article entitled, The Potential Incentives of Public Employment, 27 Am. Pol. Sci. Rev. 628 (1933). 
the taxpayer. The financial obligation resting on the management is to maintain the credit of the undertaking; so that it can raise capital as and when it needs it, and on favorable terms. So long as this is secured, all surpluses go, in effect, to the consumer.

One discovery that invariably impresses British and European visitors in the United States is the average American's cynicism regarding trusteeship in public life. Foreign observers are no doubt correct in stating that American cynicism is due largely to self-delusion as a people. We get what we expect, (or what we are taught to expect); if we demanded more we should probably get more, just as other peoples do. The British expect public utility trusts to be free from business and political wire-pulling; most Americans would expect the opposite. It is generally agreed that British public utility trusts are freer from patronage and log-rolling than are most private business concerns. Only government undertakings, like the Post Office, telegraphs, and telephones, set a higher standard in this regard. The only respect in which the disinterestedness of the public utility trust is really threatened is in its relations with closely allied commercial interests, such as manufacturers of electrical equipment, or in the temptation to spend large sums on newspaper publicity in order to prevent hostile criticism.

Generally speaking, the source of corruption in public office is the profit motive of organized interests who succeed in electing and controlling their candidates, and not the innate perversity of human nature. Government offices, and public utility trusts, are more likely to get "disinterested" (i.e. public-spirited) service than are privately-owned utilities. This is one of the great advantages of government administration of economic services as compared with government regulation of private corporations. Government has made a much greater success of running municipal light plants than it has of public utility regulation. ${ }^{37}$ Dishonesty and anti-social practices can be shielded behind the maze of regulation much more successfully than they can in the simplicity and the publicity of public corporations or government departments.

The mixed undertaking has several points in common with the public utility trust. It is a quasi-governmental corporation, it possesses monopoly privileges, and public control is exercised primarily from within rather than from without. The principal differences are that the government owns a portion of the investment, appoints some of the officials, and decides disagreements arising between government and private directors by

37 Cf. Frederick L. Bird, The Management of Small Municipal Lighting Plants (New York, 1932), and Martin G. Glaeser, Los Angeles Bureau of Power and Light, 9 Jour. Land \& Pub. Util. Econ. 217 (1933). 
an appeal to higher government officials. A mixed undertaking is a public utility service in which the government and a private company jointly subscribe the stock and cooperatively manage the service. ${ }^{38}$

The plan became popular in Germany before the war. Today almost every country in Europe, including Great Britain, has established mixed undertakings. Since the war the growth of mixed enterprises has been one of the most significant features of economic development in Western Europe. The outstanding examples are found in the fields of electricity, gas supply, and transport; but mixed undertakings also provide garage service and even milk supply. In Germany the government's share of the financial outlay usually represents more than fifty per cent of the net investment, while in France the law restricts the government's participation to forty per cent. In all countries, however, the government is amply represented on the board of directors and in the management, and reserves the right to overrule the representatives of the private stockholders in case of fundamental disagreement.

Due to the fact that the British have developed a distinctive form of public utility of their own, the public utility trust, the number of mixed undertakings which exist in Great Britain is much smaller than in most European countries. Then too, until recently the British possessed very little knowledge of mixed undertakings on the continent. ${ }^{39}$ Examples of the mixed corporation which exist in Great Britain are the Manchester Ship Canal, the Sheffield suburban transport service, the Southampton Harbor Board, and the Anglo-Persian Oil Company. Two of these undertakings have been discussed in Sir William Hart's article, but a great deal of interesting research on the subject remains to be done.

Several distinct advantages may be attributed to the mixed undertaking. In the first place, public control is exercised from within, instead of by establishing a regulatory body apart from the utility. Simplicity of administrative organization and non-interference with management are made possible. A private company which has been unable to raise funds for desirable capital expenditures has frequently been enabled to do so by a pooling of interests with the government. Securities in mixed undertakings are backed up by public credit and hence come to be considered "giltedged." On the other hand, communities which are anxious to extend government ownership of essential services, but which are limited for fi-

${ }^{8}$ For a brief analysis see Marshall E. Dimock, Les Entreprises Mixtes, 20 Nat. Muni. Rev. 638 (I93I). This article contains additional references.

${ }^{39}$ So far as the writer is aware the first and only article which has appeared on the subject in British journals is Sir William Hart's, Mixed Undertakings, 1o Public Administration I $_{3} 8$ (I932). 
nancial reasons, can make an investment in a public utility service with the idea of increasing it later. This has been the history of mixed enterprises in Germany. The tax-payers obtain a portion of monopoly profits. Then too, partial government ownership and ample government control are secured, while at the same time the experience and acumen of business management are preserved.

The disadvantages of the mixed authority are that it may lead to clashes between representatives of private and government interests, resulting in vacillation and inefficiency. So far as the writer has been able to ascertain, however, this theoretical objection has not been confirmed in practice in very many cases throughout France and Germany. Moreover, the management of mixed undertakings in Great Britain is considered very satisfactory. The Manchester Ship Canal Company has been the outstanding success..$^{\circ 0}$ Another criticism which may be brought against the mixed undertaking, however, is that the government's financial participation in the undertaking encourages the earning of large profits, and that hence the consumer's interests are not as well protected as under the public utility trust form of organization. The basic choice between the two types of utility organization seems to depend on whether direct participation in management by the government, as provided in the mixed undertaking but not in the public utility trust, affords a superior opportunity for effective public control and hence offsets the possible objection of having the government seek large profits as a means of reducing taxes or as a means of supporting other government services.

These are by no means the only important factors entering into public utility management. Forms of organization and methods of control are extremely important, but ultimately institutions are made by men, and by the ideas and attitudes of the community. A comparison of management in regulated utilities, in public utility trusts, and in government departments reveals that propagandist views relative to the intrinsic character of service under one form of organization and another are usually greatly exaggerated. All factors considered, the Post Office's management of British telephones, in which the department is assisted by a firm of public relations consultants, probably surpasses that of any other public utility in Great Britain. ${ }^{4 x}$

Our standards of comparison depend upon what we consider desirable. There is a danger that certain elements will be overemphasized to the exclusion of other necessary criteria. In the field of public utility develop-

${ }^{40}$ F. A. Eyre, The Manchester Ship Canal Company, 6 The Listener, 446 (I93I).

${ }_{4 \pi}$ The reader is referred to chapters four and five of my book, British Public Utilities. 
ment there is a peculiar need for constant philosophical consideration, and for emphasis on underlying problems of administration. Some of the hypotheses which, in view of foreign experience, deserve attention in American public utility growth, may be stated as follows. In the first place, public utilities should be administered as public services, instead of as sources of speculative profit. This may sound axiomatic, but American practices are largely disillusioning. A form of public utility organization can be established, however, in which limited dividends are incorporated as the fundamental feature. In the second place, simplicity of organization and definite responsibility should be worked toward as goals of public utility control. Again, one of the most important tests of a successful public utility is its public relations atmosphere. This should not be confused with attempts to hoodwink, stifle, or propagandize the public.

The personnel factor is all-important. Coordinators and technicians are indispensable if efficient service is to be secured, but these abilities should be coupled with a social philosophy built upon the public service ethic. Finally, a public service enterprise should protect the interests of its employees and provide room for the utilization of their abilities in management.

The United States affords a wonderful opportunity for variety and experimentation in public utility organization, management, and control. In these forty-eight laboratories of ours there might be public utility trusts, mixed undertakings, and entirely new forms of public service undertakings. The only alternative is not between private corporations and government departments, between regulation and government ownership. With our flair for invention, it is surprising that we Americans have not been in the vanguard of nations which are developing new techniques of economic development and social planning. Perhaps, now that leagues of municipalities have developed a corporate spirit, and now that regional schemes have been put under way at Muscle Shoals and at Boulder Dam, some new developments in public utility organization will occur. In the next decade good administration is likely to become much more important than regulation. This is the principal lesson to be learned from experience in other countries. 